\title{
PENGEMBANGAN MEDIA PEMBELAJARAN INTERAKTIF BERBASIS ANDROID PADA MATA PELAJARAN ALQURAN-HADIST POKOK BAHASAN MATERI INFAQ DAN SEDEKAH KELAS VIII MTS.
}

\author{
Oleh: \\ Khovadli Ocvando ${ }^{1}$ \\ Minhaji ${ }^{2}$ \\ Abd Muqit ${ }^{3}$ \\ Luluk Maktumah ${ }^{4}$ \\ Email: \\ ${ }^{1}$ Vadlikho@gmail.com \\ 2 Minhaji@ibrahimy.ac.id \\ 3 h.abd.muqit@gmail.com \\ ${ }^{4}$ Vadlikho@gmail.com \\ 5 luluadiie4@gmail.com \\ 1 UIN Maulana Malik \\ Ibrahim, Malang \\ ${ }^{2}$ Universitas Ibrahimy, \\ Situbondo \\ ${ }^{3}$ UIN Sunan Ampel, \\ Surabaya \\ ${ }^{4}$ Universitas Ibrahimy, \\ Situbondo
}

Abstract This study aims to develop Android-based interactive learning media in al-QuranHadith subjects' on the lesson of infaq and alms, class VIII MTS. This research use ADDIE (Analyse, Design, Development, Implementation, Evaluation). The results of this study 1) the majority of students already have an Android smartphone but it is still not optimal in its use in learning activities. In addition, educators are still less capable in developing interactive learning media, especially on android-based media. In this android-based interactive learning media, it contains video material for students, reviewing the material and making their own learning videos to be discussed later with the Kinemaster application tools, 2) the results of the assessment from media experts have an average score of 4,1 with category "Good," while the results of the assessment from material experts have an average score of 4,0 with category "Good." This means that the product of developing android-based interactive learning media on al-Quran-Hadith learning for class VIII on infaq and alms material is suitable to use in learning activities.

Keywords: Kinemaster, Android, Interactive Learning Media, al-Quran-Hadith.

\section{PENDAHULUAN}

Di zaman modern ini sudah tidak asing lagi di telinga kita tentang kemanfaatan teknologi dan perannya terhadap keberlangsungan hidup manusia, dari seluruh sektor yang ada mulai dari pemerintahan, sosial, ekonomi dan politik hingga pada bagian sektor Pendidikan khususnya hal tersebut memang dipengaruhi oleh masuknya era

${ }^{1}$ Agus Purwanto, "Pengembangan Aplikasi Mobile Learning Berbasis Android Sebagai Media Pembelajaran Pendidikan Agama Islam Dan Budi Pekerti Pada Materi Iman Kepada industri 4.0 yang ditandai dengan perkembangan ilmu pengetahuan dan teknologi yang begitu pesat dengan munculnya ribuan aplikasi dan platform berbasis digital, hal tersebut memang selalu beriringan dengan kebutuhan hidup manusia. ${ }^{1}$ Tidak ada yang terlepas oleh lajunya perkembangan teknologi, khususnya pada sektor pendidikan di mana dampak pandemi yang

Allah Untuk Peserta Didik Kelas XMIPA 3 SMA Negeri 1 Gemolong Tahun Pelajaran 2018/2019," Jurnal Pendidikan 28, no. 2 (2019): 2. 
memakasa peserta didik untuk melakukan pembelajaran dengan menggunakan media android, guna mengurangi mobilitas untuk memutus rantai penyebaran pandemi virus Covid-19.2

MTS Negeri 4 Harjokuncaran merupakan salah satu madrasah yang sudah tidak asing dalam penggunaan Android, hal ini didukung dengan data yang diperoleh melalui observasi dan wawancara terhadap siswa kelas VIII B, yang berjumlah 34 responden pada tahun ajaran 20212022 pada tanggal 5 oktober 2021 yang menunjukan bahwa (1) $90 \%$ peserta didik sudah menggunakan smartphone secara pribadi dan sisanya bergandengan dengan orang tua (2) berdasarkan observasi menunjukan $85 \%$ peserta didik terbiasa menggunakan android secara mandiri dan dengan memanfaatkanya untuk mencari tugas, bahkan berdasarkan data observasi dan wawancara secara tidak terstruktur menunjukan bahwa pelaksanaan ujian tengah semester ataupun pelaksanaan ujian akhir semester dilakukan menggunakan fasilitas google form dan dikerjakan melalui android smartphone masing-masing (3) berdasarkan wawancara tidak terstruktur terhadap peserta didik dapat diketahui bahwa aplikasi yang paling sering diakses oleh peserta didik adalah Whatss App, TikTok, Instagram, Youtube, Mini Editor Video (Kinemaster, Capcut), Elearning Madrasah.

Berdasarkan pemaparan di atas dapat diambil kesimpulan bahwa peserta didik secara umum sudah memiliki smartphone android secara pribadi dan sudah terbiasa mengoprasikanya, akan tetapi dalam hal ini perlu dikaji ulang bahwa penggunaan smartphone dalam konteks pembelajaran belumlah maksimal, hal tersebut dikarenakan penggunaan smartphone oleh peserta didik lebih terfokus pada orientasi bermain seperti halnya Game Mobile legend, FF, PUBG, Tiktok, Instagram, dibandingkan dengan intensitas penggunaan aplikasi pembelajaran. Hal tersebut sejalan dengan yang diungkapkan oleh Handoyono, ${ }^{3}$ yang menyatakan bahwa penggunaan smartphone oleh peserta didik kuranglah optimal hal tersebut dikarenakan hanya berorientasi pada sarana hiburan saja, seperti bermain game dan juga bersosial media. Maka dari itu sudah seyogyanya dengan dekat dan

2 Mutmainnah Muthmainnah, "Peran Orang Tua Dalam Menumbuhkan Pribadi Anak Yang Androgynius Melalui Kegiatan Bermain," Jurnal Pendidikan Anak 1, no. 1 (2015): 94, https://doi.org/10.21831/ipa.v1i1.2920.

3 A. Handoyono, N. A., \& Mahmud, "Pengembangan Media Pembelajaran Berbasis Android Pada Pembelajaran eratnya hubungan peserta didik dengan android, mereka dapat memanfaatkan fasilitas tersebut guna menunjang proses pembelajaran.

Pada bagian ini pendidik juga dirasa kurang mengambil peran dalam pemanfaat teknologi untuk melakukan kreasi dan inovasi pada penggunaan android khususnya, pendukung dari pernyataan ini adalah hasil observasi pada tanggal 20 Oktober 2021, yang menunjukan hasil bahwa dari 8 guru mata pelajaran muatan Pendidikan Agama Islam 5 memilih bahan ajar buku paket yang telah disediakan, 1 memilih ppt, 1 memilih kombinasi WA dan buku Paket, 1 memilih menggunakan Youtube dalam pelaksanaanya.

Pembelajaran yang dilakukan dengan menggunakan fasilitas teknologi yang belum dilakukan dengan optimal dapat mempengaruhi pemahaman peserta didik, hal tersebut dapat ditunjukan terhadap hasil belajar mata pelajaran Agama berupa Nilai PTS siswa kelas VIII B, di MTS Negeri 4 Harjo Kuncaran yang menunjukan hasil nilai peserta didik, yang beberapa dari responden belum mencapai Standar kriteria Ketuntasan Minimal (KKM), dari 34 responden peserta didik 29 diantaranya masih dibawah KKM yang ditentukan.

Hasil tersebut dapat memberikan gambaran bahwa masih lemahnya pemahaman konsep-konsep dasar mata pelajaran Aqidah Akhlaq yang dimiliki oleh peserta didik padahal kenyataanya materi tersebut sudah disampaikan oleh pendidik terhadap peserta didik, bahkan hingga dilakukan pengulangan pembelajaran materi yang dirasa memerlukan pengulangan dalam penjelasanya, hal tersebut disinyalir lemahnya pemanfaatan teknologi oleh pendidik dan peserta didik, sehingga konsep dalam sebuah materi pembelajaran kurang bisa tersampaikan dengan mudah terhadap peserta didik. Hal tersebut diperkuat dengan bukti penelitian sebelumnya, yang menyatakan bahwa pembelajaran IPA di SD dapat terhambat oleh kurang interaktifnya guru dalam menciptakan media pembelajaran dan dalam penggunaanya. ${ }^{4}$ Jika hal ini diabaikan secara berkelanjutan disinyalir akan dapat menurunkan tingkat pemahaman peserta didik terhadap materi.

Electronic Fuel Injection. Jurnal," Inovasi Vokasional Dan Teknologi 2 (2020): 106-15.

${ }^{4}$ Umi Christiana, Cepat Kuasai IPA SD (Jakarta: Grasindo, 2016), 78 
Dalam konteks masalah tersebut sangat diperlukan inovasi dan terobosan guna pemaanfaatan media pembelajaran berbasis android sehingga dapat meningkatkan pemahaman peserta didik dalam mendayagunakan media pembelajaran berbasis android. Penelitian berbasis android sudah pernah dilakukan sebelumnya, salah satunya dilakukan oleh Kuswanto, ${ }^{5}$ hasil dari penelitian tersebut menyatakan bahwa penggunaan android dalam media pembelajaran merupakan salah satu solusi penggunaan media pembelajaran yang praktis dan ekonomis sesuai dengan kemampuan peserta didik, kendala dalam pelaksanaanya adalah dibutuhkan android yang memiliki RAM minimal $1 \mathrm{MB}$ dan memori eksternal 4 MB. Hal tersebut juga didukung oleh penelitian sebelumnya yang menyatakan bahwa penelitian dari ahli media dan ahli materi menyebutkan bahwa penggunaan media android dalam pembelajaran memberikan dampak yang efektif yang cukup signifikan, hal tersebut dibuktikan oleh data pretest dan postest peserta didik. ${ }^{6}$ Adapun kekurangan dalam bagian ini adalah belum ditemukan aplikasi animasi dan video pembelajaran.

Berdasarkan permasalahan di atas dan beberapa solusi yang ditawarkan oleh peneliti terhadap aplikasi yang berbasis android, yang terbukti memberikan dampak positif, maka peneliti pada penelitian kali ini akan melakukan penelitian dengan mengembangkan media pembelajaran interaktif berbasis android pada materi infaq dam sedekah dengan menggunakan aplikasi Kinemaster, kedua aplikasi tersebut nantinya akan diaplikasikan dan diperankan oleh pihak masing-masing. Misal, seperti halnya, pemberi materi utama dengan aplikasi Power Point dioperasikan oleh guru atau pendidik sebagai presentator dan fasilitator utama, sedangkan aplikasi Kinemaster dioprasikan oleh peserta didik guna menghasilkan video pembelajaran dari individu masing-masing. Kinemaster merupakan aplikasi pengeditan video professional yang relative cukup mudah diaplikasikan oleh peserta didik, di samping itu apikasi ini cukup sederhana dan mudah dalam pengaplikasianya. ${ }^{7}$

Penelitian ini bertujuan untuk menghasilkan produk media pembelajaran

\footnotetext{
${ }^{5}$ J. Kuswanto, "Media Pembelajaran Berbasis Android Pada Mata Pelajaran Sistem Operasi Jaringan Kelas XI," Media Infotama 14, no. 1, (2018): 45.

6 Nurwahyuningtyas, I, "Pengembangan Media Pembelajaran Mobile Learning Berbasis Android Mata Pelajaran Ipa Untuk Siswa Smp," Jurnal Ilmiah Kependidikan 1, (2017): 8.
}

interaktif berbasis android pada pembelajaran alQuran-Hadist untuk kelas VIII pada materi infaq dan sedekah.

\section{Perumusan Masalah}

Adapun rumusan masalah dalam penelitian ini berdasarkan uraian pada latar belakang belakang di atas ialah sebagai berikut:

1. Bagaimanakah pengembangan media pembelajaran interaktif berbasis android pada pembelajaran al-Quran-Hadist untuk kelas VIII pada materi infaq dan sedekah?

2. Bagaimanakah kelayakan produk pengembangan media pembelajaran interaktif berbasis android pada pembelajaran al-Quran-Hadist untuk kelas VIII pada materi infaq dan sedekah?

\section{Tujuan Pembahasan}

Tujuan pembahasan dalam penelitian ini selaras dengan rumusan masalah sebelumnya, di antaranya sebagai berikut:

1. Bagaimanakah pengembangan media pembelajaran interaktif berbasis android pada pembelajaran al-Quran-Hadist untuk kelas VIII pada materi infaq dan sedekah?

2. Bagaimanakah kelayakan produk pengembangan media pembelajaran interaktif berbasis android pada pembelajaran al-Quran-Hadist untuk kelas VIII pada materi infaq dan sedekah?

\section{Metode Penelitian}

Pada penelitian ini menggunakan model penelitian berbasis ADDIE yang dipopulerkan oleh Raiser dan Mollenda, ADDIE merupakan penelitian dengan pendekatan Analysis-DesignDevelop-Implement-Evaluate, yang merupakan tahap tahap dalam penelitianya. Model ini memiliki prosedur penelitian yang sistematis sehingga dapat menghasilkan produk yang valid sehingga cocok untuk diujikan terhadap produk yang sedang dikembangkan. ${ }^{8}$ Pada penelitian ini implementasi tidak dilakukan, hal tersebut dikarenakan keterbatasan waktu, finansial, tenaga dan sumber daya.

Tahap analisis dilakukan melalui tiga tahapan antara lain analisis kebutuhan, kurikulum,

\footnotetext{
7 Hafizatul Khaira, "Pemanfaatan Aplikasi Kinemaster Sebagai Media Pembelajaran Berbasis ICT," Teknologi Pembelajaran 4, (2020): 40.

${ }^{8}$ K. Tegeh, I. M., Jampel, I. N., \& Pudjawan, Model Penelitian Pengembangan (Yogyakarta: Graha Ilmu, 2014), 75.
} 
dan karakteristik peserta didik, pada bagian ini yang menjadi perubahan media, model maupun metode pembelajaran merupakan dari penerapan dari media, metode maupun model pembelajaran itu sendiri. ${ }^{9}$ Langkah awal yang dilakukan oleh peneliti adalah dengan menyebar angket, melakukan observasi dan wawancara tidak terstruktur, hal tersebut dilakukan dengan tujuan guna mengetahui masalah apa yang sedang terjadi. Sebelum melakukan penelitian, peneliti menyusun kerangka awal penelitian, sebagai desain konstruksi penelitian (blue print). ${ }^{10}$ Pada tahap ini dilakukan melalui Langkah awal berupa penentuan garis besar dalam penelitian dan memadukann media-media yang diperlukan dalam sebuah penelitian.

Tahap pengembangan merupakan kelanjutan dari tahap blue print, di mana tahap ini mulai tahapan perwujudan dari tahapan sebelumnya. Dengan kata lain pada tahap ini merupakan wujud realisasi dari penggunaan media interaktif berbasis android dengan menggunakan aplikasi Kinemaster pada mata pelajaran al-Quran-Hadist dengan fokus materi infaq dan sedekah, yang kemudian dikemas dalam bentuk file, selanjutnya diberikan terhadap peserta didik, guna memperoleh data validitas pengunaan media.

Desain uji coba pada penelitian ini dilakukan hingga uji ahli dan 30 peserta didik, setelah pengujian dilakukan dan dianalisis sesuai dengan prosedur analisis data, maka diperoleh kritik dan saran. Selanjutnya dilakukan pengujian terhadap kelompok kecil dengan melibatkan peserta didik VIII B MTS Negeri 4 Harjokuncaran yang berjumlah 30 peserta didik.

Pada penelitian ini dilakukan dua pendekatan yakni pendekatan kualitatif dan kuantitatif, data kualitatif diperoleh melalui observasi, komentar para ahli dan praktisi beserta komentar saran dan juga masukan, terkait media pembelajaran hasil pengembangan. Sedangkan data kuantitatif diperoleh melalui pengisian angket oleh peserta didik yang hasilnya berupa skor. Pada penelitian ini peneliti mengguanakan instrumen skala nilai (rating scale), berupa pmeberian data chek tertentu pada data mentah di kolom yang sudah disediakan kemudian dirubah kedalam bentuk deskriptif.

\footnotetext{
9 E. Mulyatiningsih, Metode Penelitian Terapan Bidang Pendidikan. (Bandung: CV Alfabeta, 2014), 62.

10 Budi Waluyo, "Pengembangan Media Pembelajaran PAI Berbasis ICT," Jurnal An-Nur: Kajian Pendidikan Dan Ilmu Keislaman 7, no. 2 (2021): 230-50.
}

Pada penelitian ini diperoleh dua data pokok yakni data analisis dekskriptif kualitatif dan deskriptif kuantitatif, analisis deskriptif kualitatif merupakan sebuah metode dengan melakukan proses deskripsi sebuah data yang diperoleh melalui pengisian angket oleh ahli dan peserta didik. Pada saat uji coba pada kelompok kecil yang isinya berupa kritik dan saran serta masukan yang diolah secara deskriptif. Sifat Analisis deskriptif kuantitatif antara lain induktif ilmiah dan objektif terhadap data yang diperoleh dalam bentuk angka nilai dan skor dan kemudian dianalisis dalam bentuk data statistic. ${ }^{11}$ data tersebut berupa skor lembar penilaian dari ahli dan peserta didik dan diolah serta di konversi melalui pedoman skala lima.

\begin{tabular}{|l|l|}
\hline Rentang Skor & Kriteria \\
\hline $4,01<\mathrm{X} \leq 5,01$ & Sangat Baik \\
\hline $3,34<\mathrm{X} \leq 4,01$ & Baik \\
\hline $2,66<\mathrm{X} \leq 3,34$ & Cukup \\
\hline $1,99<\mathrm{X} \leq 2,66$ & Tidak Baik \\
\hline $0,99<\mathrm{X} \leq 1,99$ & Sangat Tidak Baik \\
\hline
\end{tabular}

Tabel 1: Penilaian Skala Lima

\section{Kerangka Konseptual}

\section{Media Pembelajaran Berbasis Android}

Dalam penggunaan media android di masa pandemi jika tidak disikapi dan dilakukan penggunaan secara bijak dikhawatirkan dapat menyebabkan ketergantungan dan pengguaan yang berlebih sehingga berdamapak negatif dalam sistem pembelajaranya, hal tersebut disebabkan oleh akses android yang begitu luas, dan cukup sulit untuk dibatasi, sehingga perlu dilakukan peninjauan ulang dan penguatan pemahaman terhadap peserta didik guna bijak dalam mengoperasikan android. Pembelajaran berbasis android ini bisa dimanfaatkan dalam pelaksanaan pembelajaran yang menjadi solusi guna meningkatkan sumber belajar pendidik dan peserta didik dalam literasi khususnya. Menggunakan android dalam pembelajaran diharapkan pendidik dan peserta didik dapat memperoleh hasil yang maksimal dalam mencapai tujuan pembelajaran.

Pada perkembangan industri 4.0 ditandai dengan saling beriringanya antara perkembangan

11 I. Hermawan, Penelitian Pendidikan (Kualitatif, KuantitatifDan Mixed Method). (Jakarta: Hidayatul Quran, 2019), 43. 
ilmu pengetahuan dan teknologi dengan kebutuhan manusia. ${ }^{12}$ Perkembangan ilmu pengetahuan dan teknologi ini tidak bisa dipungkiri oleh manusia, akan selalu berkembangan secara terus menerus dengan dapat ditinjau melalui munculnya situs-situs, aplikasi dan platform digital yang sudah sangat mudah dalam aksesnya. Perkembangan teknologi di era ini menjadi tantangan tersendiri terhadap pendidik dalam memfasilitasi dan memberikan pengarahan terhadap peserta didik. ${ }^{13} \mathrm{Hal}$ tersebut memang sudah menjadi konsekuensi pendididk untuk mempersiapkan peserta didiknya agar mampu menghadapi kemajuan zaman di era milenial, tantangan zaman tersebut menuntut seorang pendidik agar mampu menghasilkan sumber daya manusia yang mempuni dalam hal penguasaan ilmu pengetahuan dan teknologi. Untuk menghadapi era globalisasi, penguasaan teknologi dan ilmu pengetahuan sangatlah penting, guna mengimbangi perkembangan dan pesatnya kemajuan zaman. ${ }^{14}$

Di era globalisasi ini pendidik diharuskan mampu menyusun pembelajaran yang menarik dan komunikatif dengan peserta didik, sehingga terjadi kesinambungan diantara keduanya dan mampu mencapai tujuan pembelajaran yang diinginkan, guna menciptakan generasi bangsa yang berkualitas dan memiliki daya saing sacara global. Dalam menuju ketercapaian tujuan pendidikan tidak cukup hanya ditempuh dengan penyusunan perencanaan pembelajaran saja, akan tetapi perlu disiapkan media pembelajaran yang berkualitas dan mampu membantu tercapainya tujuan pendidikan, melalui media pembelajaran yang baik akan dapat mendorong peserta didik dalam mengikuti pembelajaran dan memainkan peranya dan meningkatkan proses pembelajaran. ${ }^{15}$

Media berasal dari kata "medium" yang dikutip dari bahasa Latin yang memiliki arti perantara atau sarana penghubung. ${ }^{16}$ Peran media adalah sebagai tumpangan materi pembelajaran

\footnotetext{
12 S Suryanti, "Pengembangan Media Game Edukatif Lecy Explore Berbasis Android Untuk Siswa Kelas IV SD Materi Siklus Hidup Hewan dan Upaya Pelestariannya," Ilmu Pendidikan 3, (2018), 45.

13 A. Sari, R. R., Febrini, D., \& Walid, "Tantangan Guru Pai Dalam Menghadapi Era Perubahan Globalisasi Teknologi Industri 4.0 Di SMA Negeri 01 Bengkulu Tengah," GHAITS A Islamic Education Journal 2, (2021): 24.

14 A. E. N. Fauzi, Pelatihan Guru Dalam Menghadapi Era Globalisasi. (Jurusan Teknologi Pendidikan, Fakultas Ilmu Pendidikan, Universitas Negeri Malang, 2020), 21.

15 Yulia Siska, Pembelajaran IPS Di SD/MI (Yogyakarta: GarudhaWaca, 2018), 104.
}

agar mudah tersampaikan terhadap peserta didik tersebut, selain metode penyampaian materi yang baik dan menarik oleh guru penggunaan media yang tepat dan menarik akan membuat peserta didik antusias dan tertarik dalam pelaksanaan pembelajaranya, ${ }^{17}$ sehingga penggunaan media pembelajaran yang tepat diharapkan dapat meningkatkan motivasi belajar peserta didik.

Perkembangan teknologi yang sangat erat dan dekat dengan perkembangan sistem pendidikan peserta didik adalah hal yang tidak bisa dipisahkan seperti halnya adalah, smartphone dan android. Rahayu dan Handayani, ${ }^{18}$ menyebutkan bahwa pembelajaran interaktif dengan menggunakan android dapat meningkatkan minat belajar peserta didik dan dapat memacu perkembangan pemahaman peserta didik sesuai dengan kemampuan mereka masing-masing. Dalam penelitian ini, penggunaan android difokuskan pada aplikasi Kinemaster. Adapun Kinemaster merupakan aplikasi pengeditan video professional yang relative cukup mudah diaplikasikan oleh peserta didik, di samping itu apikasi ini cukup sederhana dan mudah dalam pengaplikasianya. ${ }^{19}$

\section{Hasil dan Pembahasan}

\section{Pengembangan Rancangan Produk}

Fokus dalam penelitian ini merupakan produk yang dikembangkan guna menunjang ketercapaian belajar peserta didik kelas VIII B pada mata pelajaran al-Quran-Hadist materi infaq dan sedekah. Adapun media tersebut berupa penggunaan aplikasi Kinemaster pada android peserta didik.

Data analisis kebutuhan dilakukan melalui quisioner, studi dokumen dan wawancara. Hasil analisis menunjukan bahwa sebagian besar peserta didik sudah memiliki Smartphone Android secara pribadi dan sudah terbiasa dalam pengoprasianya. Akan tetapi dalam penggunaan pada pembelajaran masih kurang, karena penggunaan smartphone cenderung pada game,

${ }^{16}$ H. Sumiharsono, R., \& Hasanah, Media Pembelajaran: Buku Bacaan Wajib Dosen, Guru dan Calon Pendidik. (Yogyakarta: Pustaka Abadi, 2017), 73.

17 Tejo Nurseto, "Membuat Media Pembelajaran Yang Baik," Jurnal Ekonomi \& Pendidikan 8, (2019): 1.

${ }_{18}$ D. V. Rahayu, D., \& Handayani, "Pengembangan Media Pembelajaran Interaktif Berbasis Android Menggunakan Ispring dan Apk Builder Untuk Pembelajaran Matematika Kelas X Materi Proyeksi Vektor Jurnal 5," Matematika dan Pendidikan Matematika 5, no. 1 (2020): 12-25.

19 Hafizatul Khaira, "Pemanfaatan Aplikasi Kinemaster Sebagai Media Pembelajaran Berbasis ICT," Teknologi Pembelajaran 4, (2020): 42 
WhatsApp, Instagram, Tiktok, dan sosial media lainya. Demikian juga dengan guru yang masih relative kurang dalam mengoptimalkan penggunaan android pada kegiatan pembelajaran sesuai dengan perjalanan kemajuan dan kebutuhan zaman.

Pada tahap desain, hal yang dilakukan awal adalah penyusunan naskah materi kemudian di mulailah rancangan metode pembelajaran dan kemudian dilanjutkan dengan penyusunan materi dengan menggunakan aplikasi Kinemaster yang nantinya hal tersebut dilakukan oleh peserta didik serta dilakukan presentasi oleh mereka. Pada tahap development adalah tahap merealisasikan produk pembelajaran berbasis android dengan menggunakan aplikasi Kinemaster, media pembelajaran ini dibuat dengan standar stand alone yakni dapat berjalan dengan tanpa terhubung dengan saluran internet (offline), berikut bentuk penggunaan Aplikasi Kinemaster

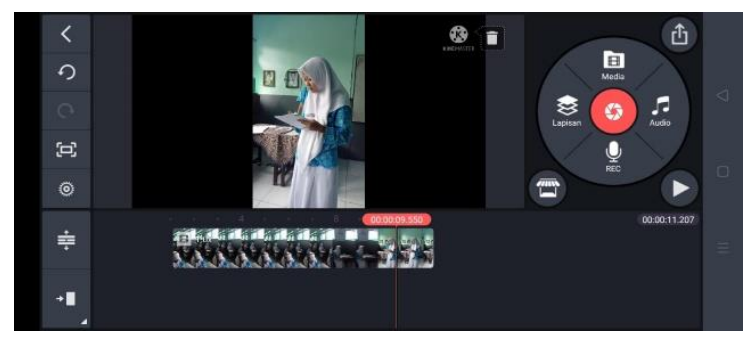

Gambar 1: Tampilan Aplikasi Kinemaster

Aplikasi media pembelajaran interaktif berbasis android ini dapat mengolaborasikan beberapa media seperti gamabar, video, backsound narasi pembelajaran. Aplikasi ini dapat dijalankan secara offline dengan rincian bahwa jenis media mempunyai karakteristik multimedia ukuran download $75 \mathrm{MB}$, pada OS minimal Android 5.0, dan RAM yang dipakai minimal RAM 2 MB. Pada media pembelajaran interaktif berbasis android ini berisikan materi video peserta didik, mereview materi dan membuat video pembelajaran mereka sendiri. Hal tersebut juga disinyalir dapat meningkatkan mental pecerto didil amor terhioc berbicara didepan kam mereka. ${ }^{20}$
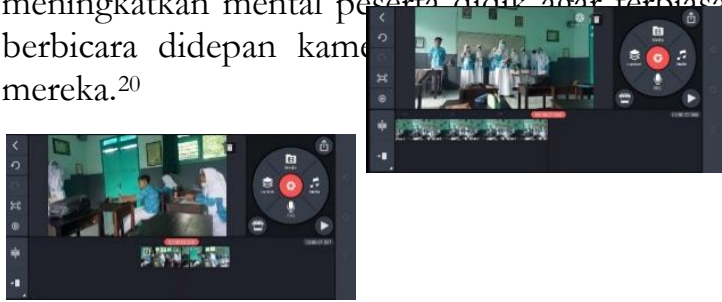

Gambar 2: Pembuatan Video Interaktif Peserta Didik

20 Hafizatul Khaira, "Pemanfaatan Aplikasi Kinemaster Sebagai Media Pembelajaran Berbasis ICT," Teknologi Pembelajaran 4, (2020): 41-42.

\section{Kelayakan Produk Pengembangan Media Pembelajaran}

Produk yang sudah dirancang berdasarkan kebutuhan dalam hasil data analisis kebutuhan selanjutnya ialah divalidasi untuk mengetahui seberapa layak produk pembelajaran yang dikembangkan. Berdasarkan proses validasi ahli materi, ahil media dan uji coba kelompok kecil diperoleh data sebagai berikut.

\begin{tabular}{|l|l|c|c|}
\hline \multirow{4}{*}{ Validator } & Aspek & $\begin{array}{c}\text { Perolehan } \\
\text { Nilai }\end{array}$ & \multirow{2}{*}{ Kategori } \\
\hline \multirow{4}{*}{ Materi } & Tampilan & 4,0 & \multirow{2}{*}{ Baik } \\
\cline { 2 - 3 } & Penyajian & 4,0 & \\
\cline { 2 - 3 } & Kebahasaan & 4,0 & \multirow{2}{*}{ Baik } \\
\hline \multirow{3}{*}{ Media } & Kemudahan & 4,5 & \\
\cline { 2 - 3 } & Kompabilitas & 4,0 & \\
\cline { 2 - 3 } & Kualitas Media & 4,0 & \\
\hline
\end{tabular}

Tabel 2: Penilaian Ahli Materi dan Ahli Media

Berdasarkan data pada tabel di atas diperoleh rata-rata dari validator ahli materi 4,0 dan validator ahli media 4,1. Berdasarkan data di atas dapat diketahui bahwa hasil penilaian dari ahli materi menunjukan angka 4,0 maka dalam hal ini menunjukan kualitas materi adalah "Baik." Penilaian yang dilakukan oleh ahli materi ini ditinjau dari 3 aspek antara lain tampilan materi yang mendapatkan skor 4,0. Sajian materi memperoleh skor 4,0 dan aspek kebahasaan memperoleh hasil 4,0. Semua memperoleh penilaian di antara rentan $3,34<\mathrm{X}<4,01$, sehingga dapat disimpulkan bahwa materi yang disampaikan sudah cukup baik karena sudah mencakup unsur unsur materi utama infaq dan sedekah, sehingga mudah dipahami oleh para pendengar, hal tersebut sejalan dengan Sanjaya bahwa materi yang dibuat pada aktivitas pembelajaran harus mempunyai kualitas isi yang mudah dipahami. ${ }^{21}$

Penilaian selanjutnya dilakukan oleh penilai media, dan diperoleh rata-rata skor 4,1 dalam rentang penilaian 0,0-5,0. Hal tersebut menunjukan bahwa angka penilaian kualitas media masuk kedalam kategori "Baik." Pada bagian penilai media beberapa aspek yang dinilai antara lain ialah aspek kemudahan, yang memperoleh skor 4,5. Aspek kompabilitas menunjukkan hasil perolehan skor sebesar 4,0 dan pada aspek kualitas media memperoleh hasil penilaian sebesar 4,0. dalam penilaian tersebut

21 Wina Sanjaya, Media Komunikasi Pembelajaran. (Jakarta: PT Kharisma Putra Utama, 2012), 85. 
diketahui bahwa media pembelajaran menggunakan editor video berbasis Kinemaster sangat baik dalam penyusunan materi oleh peserta didik, selain itu media tersebut juga relative mudah diaplikasikan oleh peserta didik. Pada aplikasi ini juga memiliki kualitas gambar dan suara yang cukup baik, serta dilengkapi dengan animasi dan efek-efek yang dapat membuat tampilan video tersebut lebih menarik, hal tersebut sejalan dengan apa yang telah diutarakan oleh Rohinah bahwa kebmudahan dalam mengakses aplikasi dapat meningkatkan ketertarikan dan kenyamanan peserta didik sehingga dapat membuat antusiasme yang tinggi dari peserta didik dalam melaksanakan proses pembelajaran. Hal tersebut sejalan dengan yang diungkapkan oleh Novitasari tentang teknik penggabungan animasi, gambar dan fitur-fitur yang ada dalam sebuah aplikasi dapat meningkatkan antusias peserta didik dan meminimalisir kebosanan peserta didik dalam proses pembelajaran. ${ }^{22}$

Selain memperoleh nilai kelayakan dari ahli materi dan ahli media, hal yang terpenting juga ialah sarang dari kedua validator ahli tersebut. Hal ini ditujukan untuk penyempurnaan produk yang relevan yang juga akan dikembangkan baik oleh peneliti lain atau pun oleh peneliti yang bersangkutan. Adapun saran yang didapati dari penilai media adalah, teknik editor dan penyusunan video yang lebih baik dan lebih runtut, serta penataan backsound dengan narasi yang dibawakan oleh peserta didik diharapkan lebih dipersiapkan kembali. Hal tersebut bertujuan agar suara antara narasi dan bcksound haruslah sesuai dengan kebutuhan.

\begin{tabular}{|c|l|c|l|}
\hline Responden & Aspek & $\begin{array}{c}\text { Perolehan } \\
\text { Nilai }\end{array}$ & Kategori \\
\hline \multirow{5}{*}{ Siswa } & $\begin{array}{l}\text { Manfaat } \\
\text { Media }\end{array}$ & 4,5 & \\
\cline { 2 - 4 } & $\begin{array}{l}\text { Antusiasme } \\
\text { Peserta } \\
\text { Didik }\end{array}$ & 4,7 & $\begin{array}{l}\text { Sangat } \\
\text { Baik }\end{array}$ \\
\hline
\end{tabular}

Tabel 3: Respon Siswa

Setelah dilakukan peninjauan dari ahli materi dan ahli media, selanjutnya dilakukan pengujian terhadap peserta didik kelas VIII B, Mts Negeri 4 Harjokuncaran, yang diperoleh hasil rata-rata skor 4,6. Dari nilai yang diperoleh tersebut dapat disimpulkan bahwa hasil uji coba

22 D Novitasari, "Pengaruh Penggunaan Multimedia Interaktif Terhadap Kemampuan Pemahaman Konsep Matematis Siswa.," FIBONACCI: Jurnal Pendidikan Matematika dan Matematika 2 (2016): 8-18. terhadap kelompok kecil peserta didik bisa dikategorikan "Sangat Baik." Penilaian pada tahap uji coba di kelompok kecil, peserta didik ini ditargetkan pada tinjauan 2 aspek yakni manfaat media dan antusiasme peserta didik. Pada aspek kemanfaatan media memperoleh skor sebesar 4,5. Sedangkan pada aspek antusiasme peserta didik mendapatkan perolehan skor sebesar 4,7. Dengan demikian dapat disimpulkan bahwa penggunaan media pembelajaran melalui Kinemaster ialah efektif dalam menarik antusias peserta didik, dan relevan diterapkan dalam penerapan di sekolah.

Beberapa catatan yang diperoleh dalam proses uji coba terhadap kelompok kecil peserta didik antara lain ialah peserta didik merasa tidak bosan ketika mengikuti aktivitas proses pembelajaran. Selaiitu peserta didik merasa lebih bisa mengeksplor model pemikiran mereka dan peserta ddik lebih terpupuk karakter mental dan persiapan jiwa mereka guna tampil didepan kamera. Sehingga dapat ditarik sintesa bahwa peserta didik bisa lebih menikmati proses pembelajaran dengan proses pembelajaran yan serasa sama seperti sedang bermain game.

Penggunaan media berbasis android dapat mememikat perhatian peserta didik yang pada akhirnya dapat meningkatkan motivasi belajar peserta didik. Siswa akan lebih tertarik dalam pembelajaran yang bersifat kombinasi antara gambar, suara, narasi dan lain sebagainya, sehingga dapat meningkatkan minat belajar peserta didik dan pada akhirnya dapat mencapai tujuan belajar peserta didik. Hal ini sejalan pada penelitian sebelumnya juga banyak dlakukan oleh peneliti-peneliti lain dengan tema serupa, Amajida pada penelitianya memperoleh data rata-rata dari ahli media 4,5 dan rata-rata dari ahli materi ratarata 4 sehingga jika diakumulasikan maka diperoleh akumulasi nilai sejumlah 4,25 yang menunjukan arti "Sangat Baik" jika diukur dalam rentang angka 4,1<x $<5,0$ maka dengan demikian dapat disimpulkan bahwa media pembelajaran berbasis android ini dapat dikatakan layak digunakan di sekolah, menurut kuswanto menggunakan media pembelajaran berbasis android merupakan solusi media pembelajaran yang ditawarkan untuk peserta didik karena hal tersebut praktis digunakan, mudah dan sesuai dengan fasilitas yang dimiliki peserta. ${ }^{23}$ akan tetapi pada penelitian media pembelajaran ini yang telah digunakan, memiliki kelemahan berupa

${ }^{23}$ J. Kuswanto, "Media Pembelajaran Berbasis Android Pada Mata Pelajaran Sistem Operasi Jaringan Kelas XI," Jurnal Media Infotama 1 (2019): 14 
memerlukan media berbasis android dengan kapasitas RAM minimal 1 GB, jika mengacu pada tahun penelitian tersebut jumlah android dan smartphone pada tahun tersebut masih banyak yang memiliki RAM di bawah 1 GB akan tetapi pada tahun ini di mana smartphone sudah rata-rata memiliki RAM minimal 3 GB. ${ }^{24}$ Sehingga hal tersebut sudah tidak menjadi kendala.

Berdasarkan penelitian-penelitian yang dilakukan sebelumnya, yang dilakukan dengan melakukan berbagai cara dan metode yang berbeda, akan tetapi memperoleh hasil yang sama, demikian juga dengan penelitian yang dilakukan oleh peneliti, tetap diperoleh hasil yang sama. Yakni menggunakan aplikasi berbasis android pada proses pembelajaran dapat memperoleh antusiasme yang tinggi dari peserta didik, sehingga dapat disintesakan bahwa penggunaan media pembelajaran berbasis android pada peserta didik relevan digunakan, hal tersebut dibuktikan dengan bentuk respon yang sangat baik dari peserta didik dan pendidik sebagai praktisi kelas.

Pada penelitian ini ditemukan beberapa kelebihan dan kekurangan diantaranya sebagai berikut. Kelebihan yang ditemui oleh peneliti di antaranya adalah aplikasi Kinemaster dapat diinstal pada perangkat Smartphone dengan kapasitas minimal RAM 1 GB sehingga ketika diujikan kepada kelompok kecil dapat dilakukan oleh seluruh peserta didik karena relatif ringan. Selain itu, media pembelajaran berbasis android dengan menggunakan aplikasi editor video Kinemaster dapat menghasilkan video pembelajaran yang isinya memuat kombinasi, dari gambar, suara, video animasi dan teks, yang di mana hal tersebut diminati dan digemari oleh peserta didik. Hal demikian terbukti dengan hasil penilaian dari kelompok kecil yang menyatakan ketertarikan mereka terhadap media pembelajaran berbasis video tersebut sangat besar. Media pembelajaran yang telah dikembangkan juga dapat memenuhi hasrat intelektual peserta didik berupa kelenturan berekspresi dan berpendapat atas materi yang diajarkan, sehingga di sini bisa dilakukan pembelajaran aktif dan interaktif, dengan guru sebagai fasilitator saja, hal tersebut dibuktikan dengan peserta didik yang dapat menjelaskan materinya sendiri melalui video yang mereka buat.

Pada media pembelajaran berbasis android dengan menggunakan aplikasi editor video Kinemaster ini ditemukan beberapa

24 Hafizatul Khaira, "Pemanfaatan Aplikasi Kinemaster Sebagai Media Pembelajaran Berbasis ICT," Teknologi Pembelajaran 4, (2020): 40. kelemahan antara lain ialah pada penelitian ini masih dalam tahap pengembangan (development) sehingga nilai validitas pada penelitian ini masih relative rendah karena hanya dilakukan pada lingkup kelompok kecil sehingga perlu dilakukan pengujian terhadap kelompok yang lebih besar. Eksplor materi oleh peserta didik kurang luas dan hanya bersifat deskriptif tekstual, sehingga perlu pendampingan materi terhadap peserta didik. Pengembangan media pembelajaran dengan menggunakan Kinemaster, dirasa kurang memiliki eksplor video yang kurang luas, sehingga perlu dilakukan kombinasi dengan media pembelajaran yang lain semisal seperti dengan filter Instagram, filter Tiktok dan lain sebagainya menyesuaikan dengan kecenderungan sosial media peserta didik, sehingga dapat menambah semangat peserta didik terhadap substansi pembelajaran.

\section{SIMPULAN}

1. Mayoritas peserta didik telah memiliki smartphone android namun masih belum optimal dalam penggunaannya diaktivitas pembelajaran. Di samping itu, pendidik masih kurang mampu dalam mengembangkan media pembelajaran interaktif, terutama pada media berbasis android. Pada media pembelajaran interaktif berbasis android ini berisikan materi video peserta didik, mereview materi dan membuat video pembelajaran mereka sendiri untuk nantinya didiskusikan bersama.

2. Hasil penilaian dari ahli media mempunyai skor rata-rata sebesar 4,1 dalam kategori "Baik," sedangkan hasil penilaian dari ahli materi mempunyai skor rata-rata sebesar 4,0 dalam kategori "Baik." Artinya produk pengembangan media pembelajaran interaktif berbasis android pada pembelajaran al-Quran-Hadist untuk kelas VIII pada materi infaq dan sedekah layak digunakan pada aktivitas pembelajaran.

\section{DAFTAR RUJUKAN}

A. E. N. Fauzi, Pelatihan Guru Dalam Menghadapi Era Globalisasi. Jurusan Teknologi Pendidikan, Fakultas Ilmu Pendidikan, Universitas Negeri Malang, 2020.

A. Handoyono, N. A., \& Mahmud, "Pengembangan Media Pembelajaran Berbasis Android Pada Pembelajaran Electronic Fuel Injection. Jurnal,” Inovasi 
Vokasional Dan Teknologi 2 (2020): 10615.

A. Sari, R. R., Febrini, D., \& Walid, "Tantangan Guru Pai Dalam Menghadapi Era Perubahan Globalisasi Teknologi Industri 4.0 Di SMA Negeri 01 Bengkulu Tengah," GHAITSA Islamic Education Journal 2, (2021): 24.

Agus Purwanto, "Pengembangan Aplikasi Mobile Learning Berbasis Android Sebagai Media Pembelajaran Pendidikan Agama Islam Dan Budi Pekerti Pada Materi Iman Kepada Allah Untuk Peserta Didik Kelas XMIPA 3 SMA Negeri 1 Gemolong Tahun Pelajaran 2018/2019,’ Jurnal Pendidikan 28, no. 2 (2019): 2.

Budi Waluyo, "Pengembangan Media Pembelajaran PAI Berbasis ICT," Jurnal An-Nur: Kajian Pendidikan Dan Ilmu Keislaman 7, no. 2 (2021): 230-50.

D Novitasari, "Pengaruh Penggunaan Multimedia Interaktif Terhadap Kemampuan Pemahaman Konsep Matematis Siswa.," FIBONACCI: Jurnal Pendidikan Matematika dan Matematika 2 (2016): 818.

D. V. Rahayu, D., \& Handayani, "Pengembangan Media Pembelajaran Interaktif Berbasis Android Menggunakan Ispring dan Apk Builder Untuk Pembelajaran Matematika Kelas X Materi Proyeksi Vektor Jurnal 5," Matematika dan Pendidikan Matematika 5, no. 1 (2020): 12-25.

E. Mulyatiningsih, Metode Penelitian Terapan Bidang Pendidikan. (Bandung: CV Alfabeta, 2014), 62.

H. Sumiharsono, R., \& Hasanah, Media Pembelajaran: Buku Bacaan Wajib Dosen, Guru dan Calon Pendidik. Yogyakarta: Pustaka Abadi, 2017.

Hafizatul Khaira, "Pemanfaatan Aplikasi Kinemaster Sebagai Media Pembelajaran Berbasis ICT," Teknologi Pembelajaran 4, (2020): 40 .

I. Hermawan, Penelitian Pendidikan (Kualitatif, Kuantitatif Dan Mixed Method). Jakarta: Hidayatul Quran, 2019.

J. Kuswanto, "Media Pembelajaran Berbasis Android Pada Mata Pelajaran Sistem Operasi Jaringan Kelas XI," Media Infotama 14, no. 1, (2018): 45.
J. Kuswanto, "Media Pembelajaran Berbasis Android Pada Mata Pelajaran Sistem Operasi Jaringan Kelas XI," Jurnal Media Infotama 1 (2019): 14.

K. Tegeh, I. M., Jampel, I. N., \& Pudjawan, Model Penelitian Pengembangan (Yogyakarta: Graha Ilmu, 2014), 75.

Mutmainnah Muthmainnah, "Peran Orang Tua Dalam Menumbuhkan Pribadi Anak Yang Androgynius Melalui Kegiatan Bermain," Jurnal Pendidikan Anak 1, no. 1 (2015): 94 https://doi.org/10.21831/jpa.v1i1.2920

Nurwahyuningtyas, I, "Pengembangan Media Pembelajaran Mobile Learning Berbasis Android Mata Pelajaran Ipa Untuk Siswa Smp," Jurnal Ilmiah Kependidikan 1, (2017): 8.

S Suryanti, "Pengembangan Media Game Edukatif Lecy Explore Berbasis Android Untuk Siswa Kelas IV SD Materi Siklus Hidup Hewan dan Upaya Pelestariannya," Ilmu Pendidikan 3, (2018), 45.

Tejo Nurseto, "Membuat Media Pembelajaran Yang Baik," Jurnal Ekonomi \& Pendidikan 8, (2019): 1.

Umi Christiana. Cepat Kuasai IPA SD. Jakarta: Grasindo, 2016.

Wina Sanjaya, Media Komunikasi Pembelajaran. Jakarta: PT Kharisma Putra Utama, 2012.

Yulia Siska, Pembelajaran IPS Di SD/MI. Yogyakarta: GarudhaWaca, 2018. 